\title{
RĪGAS LIELMĒROGA DZĪVOJAMO RAJONU DAŽĀDĪBA IEDZĪVOTĀJU SASTĀVA UN DZİVES VIDES PIEVILCĪBAS VĒRTĒJUMĀ
}

\author{
Rihards Provejs, Māris Bērziņš, Zaiga Krišjāne \\ LU G̣eogrāfijas un Zemes zinātṇu fakultāte, \\ e-pasts: get3@inbox.Iv, maris.berzins@lu.lv, zaiga.krisjane@lu.lv
}

\begin{abstract}
Anotācija. Lielmēroga dzīvojamie rajoni veido nozīmīgu pilsētvides daḷu daudzās Eiropas pilsētās. Viduseiropā un bijušās Padomju Savienības teritorijā šo dzīvojamo rajonu attīstībā kopš 20.gs. 90. gadiem notikušas ievērojamas pārmaiṇas. Līdzšinējo pētījumu pieredze rāda, ka, lai gan ir liels iedzīvotāju skaits un dominējoša loma mājokḷu sektorā, lielmēroga dzīvojamo rajonu iedzīvotāju sastāvs un dzīves vides pievilcība joprojām ir maz pētīti un analizēti aspekti postpadomju pilsētās. Turklāt agrāk veikti pētījumi atklāj, ka mājokḷu politikas un standartu attīstība sociālisma periodā, kā arī dažādu dzīvojamo rajonu izbūves, novietojuma un vides aspekti nosaka ne tikai arhitektoniskās atškiirības starp lielmēroga dzīvojamiem rajoniem, bet arī to sociālo statusu un kopējo dz̄ives vides pievilcību. Tāpēc šajā rakstā pētīti gan dzīves vides pievilcības aspekti, gan iedzīvotāju sastāvs divās Rīgas apkaimēs, kur dominē pēc vēsturiskās attīstības atšķirīga lielpaneḷu dzīvojamo ēku apbūve. Tas darīts ar nolūku, lai labāk izprastu lielmēroga dzīvojamo rajonu galvenās attīstības iezīmes un iespējamās atškirības postpadomju pilsētās. Lielmēroga dzīvojamo rajonu izpētē šajā rakstā izmantoti 2015. gadā veiktas Rīgas iedzīvotāju aptaujas dati. Darbā iegūtie rezultāti kopumā neatklāj būtiskas atšķirības dzīves vides pievilcības vērtējumā izpētei izvēlētajās apkaimēs.
\end{abstract}

Atslēgas vārdi: lielmēroga dz̄̄vojamie rajoni, dzīves vides pievilcība, sociāli telpiskā dažādība, postpadomju pilsētas.

\section{Ievads}

Dzīvojamā apbūve veido būtisku pilsētas telpiski funkcionālās struktūras daḷu. Daudzās Eiropas pilsētās lielmēroga dzīvojamie rajoni ir redzamākā apbūves forma un daudzu pilsētnieku mājvieta. Austrumeiropas un Viduseiropas, kā arī bijušās Padomju Savienības teritorijā daudzstāvu dzīvojamās apbūves rajoni ir sastopami biežāk nekā Rietumeiropas pilsētās. Tas saistīts gan ar sociālisma periodam raksturīgajiem urbanizācijas un industrializācijas procesiem, gan arī sociālisma iekārtas ideologiiskajiem, politiskajiem un sociāli ekonomiskajiem mērḳiem (French, Hamilton 1979; Smith 1996; Kempen van et al. 2005). Rīgā, atbilstoši pēdējās tautas skaitīšanas datiem, padomju periodā celtajos mājokḷos dzīvo aptuveni $70 \%$ pilsētas iedzīvotāju. Tādējādi arī mūsdienās tipisks rīdzinieku mājoklis ir atsevišķs dzīvoklis daudzstāvu dzīvojamā ēkā, kas celta sociālisma periodā. Kop̌̌ valsts neatkarības atgūšanas 1991. gadā dažādu politisko un sociāli ekonomisko pārmaiņu rezultātā mainījās arī lielmēroga dzīvojamie rajoni. Rīgas pilsētvides attīstības kontekstā šo rajonu dzīves vides pievilcības aspekti un iedzīvotāju sastāva īpatnības ir aktuāli izpētes jautājumi. Turklāt vairāki autori uzsver, ka, lai gan lielmēroga dz̄̄vojamiem rajoniem ir nozīmīga loma, tie postpadomju pilsētās ir visai maz pētīti un analizēti (Treija 2009; Kahrik, Tammaru 2010).

Līdzšinējo pētījumu pieredze rāda, ka lielmēroga dz̄ivojamo rajonu sociāli telpiskās attīstības iezīmes postpadomju pilsētās ir pretrun̄̄ga tēma. Daži pētnieki apgalvo, ka postsociālisma apstākḷ̆os notiekošo politisko, ekonomisko, demogrāfisko, sociālo un 
vides faktoru ietekmē ievērojami mainās mājokḷu tirgus un lielmēroga dzīvojamie rajoni, iedzīvotājiem pārceḷoties uz citu dzīvesvietu, zaudē savu agrāko pievilcību (Smith 1996; Wassenberg 2004). Atsevišķu autoru skatījumā šo dzīvojamo rajonu nākotnes perspektīvas bija drūmas - tika norādīts uz dzīves vides sociāli telpisko marginalizāciju, turīgāko iedzīvotāju aizplūšanu, pieaugošu etnisko segregāciju, padomju periodā celto ēku morālu un fizisku nolietojumu (Szelenyi 1996; Wießner 1999; Glock, Haußermann 1996). Jaunāki pētījumi vairākās postsociālisma pilsētās tomēr noraida drūmos scenārijus un atklāj, ka lielmēroga dzīvojamie rajoni saglabā daudzveidīgu sociālo struktūru un tur dzīvojošo iedzīvotāju vērtējumā tiek raksturoti kā pievilcīga dzīves vide (Kahrik, Tammaru 2010; Herfert et al. 2013). Tomēr vairāki pētījumi atklāj, ka mājokḷu politikas un standartu attīstība sociālisma periodā, kā arī dažādu dzīvojamo rajonu izbūves, novietojuma un vides aspekti, nosaka ne tikai arhitektoniskās atškirīibas starp lielmēroga dzīvojamiem rajoniem, bet arī to sociālo statusu un kopējo dzīves vides pievilcību (Pichler-Milanovich 2001; Temelova et al. 2011). Austrumeiropā un Viduseiropā, kā arī bijušās Padomju Savienības teritorijā lielpaneḷu dzīvojamo ēku celtniecība sākās 20. gadsimta 50. gadu otrajā pusē, bet masveidīga šo ēku celtniecība pēc rajonu apbūves principa sākās 60. gados (French 1987). Sākotnēji celtās ēkas bija sliktākas kvalitātes, dzīvokḷi bija nelieli un to plānojums vienkāršs (Szelenyi 1996; Lehmann, Ruble 1997; Rubīns 2004; Boren, Gentile 2007). Vēlākajās desmitgadēs 70. un 80. gados palielinājās gan ēku stāvu skaits un dzīvokḷu lielums, gan arī tika uzlabots to labiekārtojums un plānojums (Lehmann, Ruble 1997; Smith 1996; Treija 2009). Turklāt jau padomju periodā neapmierinoša ēku ekspluatācija un nepietiekama līdzekḷu ieguldīšana to uzturēšanā ievērojami pasliktināja tieši vecāko daudzstāvu ēku stāvokli (Kahrik, Tammaru 2010). Līdz ar to ir pamats uzskatīt, ka sociāli telpiskās un dzīves vides pievilcības atšḳirības būs vērojamas dažādos laika periodos celtos lielmēroga dz̄ivojamos rajonos. Turklāt var pieņemt, ka postsociālisma pārmaiņu rezultātā šîs atšķirības būs tikai pastiprinājušās. Darbā tiek pētīts iedzīvotāju sastāvs un dzīves vides vērtējums pilsētas apkaimēs, kur apbūvē dominē lielmēroga dz̄̄vojamie rajoni. Šim mērḳim izvēlētas divas pēc iedzīvotāju skaita salīdzināmas, bet pēc ēku celtniecības perioda atškirīgas apkaimes. Turklāt izvēlētās apkaimes - Ķengarags un Pḷavnieki - ir Rīgai raksturīgi padomju perioda apbūves mikrorajoni.

\section{Dati un metodes}

Rīgas lielpaneḷu dzīvojamo rajonu izpētē izmantotas plašāk lietotās datu ieguves, apstrādes un analīzes metodes. Pētījumam izvēlēto lielmēroga dzīvojamo rajonu iedzīvotāju sastāvs un dzīves vides pievilcība analizēta, izmantojot jaunāko Rīgas pilsētas iedzīvotāju aptauju. Apsekojums veikts Rīgas domes Pilsētas attīstības departamenta uzdevumā. Aptaujas anketas izstrādē pašvaldība sadarbojās ar LU G̣ZZF Cilvēka geogrāfijas katedru, bet lauka darbu 2015. gadā veica uzṇēmums, kas specializējies sociologiisko aptauju veikšanā. Cilvēka ǵeogrāfijas katedra sagatavoja aptaujas anketas jautājumu bloku par iedzīvotāju migrācijas un ikdienas mobilitāti, kā arī piedalījās citu aptaujas anketas jautājumu sagatavošanā un apspriešanā. Pavisam 
aptaujas anketā ietverti aptuveni 80 dažādi respondentu dzīvesvietu un darba gaitas atspoguḷojoši jautājumi, t.sk. par migrāciju, pārcelšanās iemesliem un ikdienas pārvietošanos, kā arī liels jautājumu bloks par dzīves vides pievilcību raksturojošiem rādītājiem. Atsevišķs anketas bloks sniedza vispārēju respondentu sociāli demogrāfisko raksturojumu. Rakstam nepieciešamie dati atlasīti jaunā datu masīvā par darbā aplūkotajām apkaimēm. Kopējais 2015. gada aptaujā sasniegtās izlases $(N)$ apjoms ir 2043 respondenti vecumā no 18 līdz 78 gadiem (Rīgas dome 2015). Savukārt darbā izmantoti dati par 157 respondentiem Ķengaraga un 145 respondentiem Pḷavnieku apkaimē. Iegūto aptaujas datu apstrādē izmantotas neparametriskās metodes. Lai noskaidrotu iedzīvotāju sastāvu un dzīves vides pievilcību raksturojošo pazīmju saistību būtiskumu, izmantots kontingences koeficients $\left(K_{k}\right)$ (Paura, Arhipova 2002). Rezultātu pārbaude veikta, aprēḳinot to abpusējās alternatīvas $p$ vêrtību. Aprēkinātā $p$ vērtība parāda rezultātu statistisko nozīmību, savstarpēji salīdzinot atlasītās pazīmes. Tur, kur statistiskās nozīmības vērtība ir mazāka par 0,05 ar 95\% varbūtību varam apstiprināt, ka saistība starp aplūkotajām pazīmēm ir statistiski nozīmīga.

\section{Rezultāti un galvenie secinājumi}

Darbā vispirms salīdzināts respondentu sastāvs abās pētījuma apkaimēs. Iedzīvotāju sastāvs analizēts, izmantojot raksturīgākās sociāli demogrāfiskās pazīmes (1. tabula).

Tabulā redzamie rezultāti parāda, ka kopumā dzīves vides pievilcības vērtējumā starp izpētei izvēlētajām apkaimēm nav būtisku atšķirību. Nedaudz kritiskāki savas dzīves vides vērtējumā ir Pḷavnieku apkaimē dzīvojošie. Dzīvesvietas apkaimes vides pievilcība apmierina galvenokārt gados vecākus iedzīvotājus, nedaudz vairāk krievu tautības cilvēkus, kā arī iedzīvotājus ar pamata un vidējo izglīī̄bu. Tāpat nedaudz vairāk apmierināti ar dzīves vidi ir vienas personas mājsaimniecībās dzīvojoši un gimenes bez bērniem. Iegūtie rezultāti starp aplūkotajām iedzīvotāju sastāva pazīmēm un apmierinātības ar dz̄̄ves vidi novērtējumu ir statistiski nozīmīgi pēc dzimuma, vecuma grupām un ǵimenes stāvokḷa Pḷavnieku apkaimē, bet pēc mājsaimniecības lieluma un gimenes sastāva abās apkaimēs. Būtisks aspekts, ko vēlējāmies noskaidrot saistībā ar dzīves vides pievilcību, ir tās vērtējums atkarībā no tā, cik ilgi respondenti pašreizējā dz̄̄vesvietā dzīvojuši (1. attēls).

Rīgas iedzīvotāju apsekojuma kopējie rezultāti rāda, ka aptuveni trešdaḷa $(29,9 \%)$ aptaujāto pašreizējā dzīvesvietā dzīvo kopš dzimšanas un aptuveni tikpat liela daḷa (27,3\%) dzīvesvietu mainījuši pilsētas robežās (Rīgas dome 2015). Pārējo respondentu iepriekšējā dzīvesvieta atradusies ārpus Rīgas. Starp pētījumam izvēlētajām apkaimēm redzamas atšķirības. Pirmkārt, Ķengaragā vairums respondentu dzīvo ilgstoši, un viņus dzīves vide vairāk apmierina, nekā neapmierina. Otrkārt, abās apkaimēs ar dzīves vidi vairāk neapmierināto ir to aptaujāto vidū, kas dzīvesvietu ir mainījuši. Turklāt Pḷavnieku apkaimē šādu iedzīvotāju ir daudz vairāk, salīdzinot ar Ķengaragu. Tāpēc arī dzīves vides pievilcības vērtējumā ir lielāka viedokḷu dažādība. 
1.tabula. Respondentu sastāvs un dzīves vides pievilcības vērtējums pētījumam izvēlētajās apkaimēs

\begin{tabular}{|c|c|c|c|c|c|}
\hline & \multicolumn{2}{|c|}{ Kengarags } & \multicolumn{2}{|c|}{ Pḷavnieki } \\
\hline & & apmierina & $\begin{array}{c}\text { neapmierin } \\
\mathrm{a}\end{array}$ & apmierina & $\begin{array}{c}\text { neapmierin } \\
\text { a }\end{array}$ \\
\hline \multirow{3}{*}{ Dzimums } & sieviete & $62 \%$ & $63 \%$ & $73 \%$ & $80 \%$ \\
\hline & vīrietis & $38 \%$ & $37 \%$ & $27 \%$ & $20 \%$ \\
\hline & $K_{k}$ & \multicolumn{2}{|c|}{$0,155(p=0,423)$} & \multicolumn{2}{|c|}{$0,266(p=0,026)$} \\
\hline \multirow{7}{*}{ Vecuma grupa } & $15-24$ & $4 \%$ & $0 \%$ & $7 \%$ & $10 \%$ \\
\hline & $25-34$ & $12 \%$ & $12 \%$ & $15 \%$ & $10 \%$ \\
\hline & $35-44$ & $27 \%$ & $63 \%$ & $18 \%$ & $37 \%$ \\
\hline & $45-54$ & $18 \%$ & $13 \%$ & $10 \%$ & $9 \%$ \\
\hline & $55-64$ & $24 \%$ & $12 \%$ & $36 \%$ & $17 \%$ \\
\hline & $65-74$ & $15 \%$ & $0 \%$ & $14 \%$ & $17 \%$ \\
\hline & $K_{k}$ & \multicolumn{2}{|c|}{$0,305(p=0,712)$} & \multicolumn{2}{|c|}{$0,420(p=0,050)$} \\
\hline \multirow{4}{*}{ Tautība } & latvietis & $34 \%$ & $50 \%$ & $34 \%$ & $40 \%$ \\
\hline & krievs & $54 \%$ & $38 \%$ & $53 \%$ & $53 \%$ \\
\hline & cita & $12 \%$ & $12 \%$ & $13 \%$ & $7 \%$ \\
\hline & $K_{k}$ & \multicolumn{2}{|c|}{$0,273(p=0,125)$} & \multicolumn{2}{|c|}{$0,258(p=0,241)$} \\
\hline \multirow{4}{*}{ Izglītība } & pamata & $8 \%$ & $0 \%$ & $4 \%$ & $0 \%$ \\
\hline & vidējā & $85 \%$ & $63 \%$ & $69 \%$ & $63 \%$ \\
\hline & augstākā & $7 \%$ & $37 \%$ & $27 \%$ & $37 \%$ \\
\hline & $K_{k}$ & \multicolumn{2}{|c|}{$0,338(p=0,207)$} & \multicolumn{2}{|c|}{$0,342(p=0,258)$} \\
\hline \multirow{4}{*}{$\begin{array}{l}\text { Mājsaimniecības } \\
\text { lielums }\end{array}$} & 1 persona & $35 \%$ & $0 \%$ & $20 \%$ & $17 \%$ \\
\hline & 2 personas & $30 \%$ & $62 \%$ & $34 \%$ & $23 \%$ \\
\hline & $\begin{array}{l}3 \text { un vairāk } \\
\text { personas }\end{array}$ & $35 \%$ & $38 \%$ & $46 \%$ & $60 \%$ \\
\hline & $K_{k}$ & \multicolumn{2}{|c|}{$0,354(p=0,004)$} & \multicolumn{2}{|c|}{$0,336(p=0,020)$} \\
\hline \multirow{4}{*}{ G̣imenes stāvoklis } & neprecējies & $1 \%$ & $0 \%$ & $13 \%$ & $10 \%$ \\
\hline & precējies / kopdzīve & $53 \%$ & $50 \%$ & $55 \%$ & $63 \%$ \\
\hline & šḳīies* & $46 \%$ & $50 \%$ & $32 \%$ & $27 \%$ \\
\hline & $K_{k}$ & \multicolumn{2}{|c|}{$0,424(p=0,001)$} & \multicolumn{2}{|c|}{$0,314(p=0,199)$} \\
\hline \multirow{3}{*}{$\begin{array}{l}\text { Nepilngadīgi bērni } \\
\text { gimenē }\end{array}$} & ir & $45 \%$ & $63 \%$ & $39 \%$ & $46 \%$ \\
\hline & nav & $55 \%$ & $37 \%$ & $61 \%$ & $54 \%$ \\
\hline & $K_{k}$ & \multicolumn{2}{|c|}{$0,284(p=0,008)$} & \multicolumn{2}{|c|}{$0,406(0,000)$} \\
\hline & & \multicolumn{2}{|c|}{$\mathrm{N}=157$} & \multicolumn{2}{|c|}{$\mathrm{N}=145$} \\
\hline
\end{tabular}

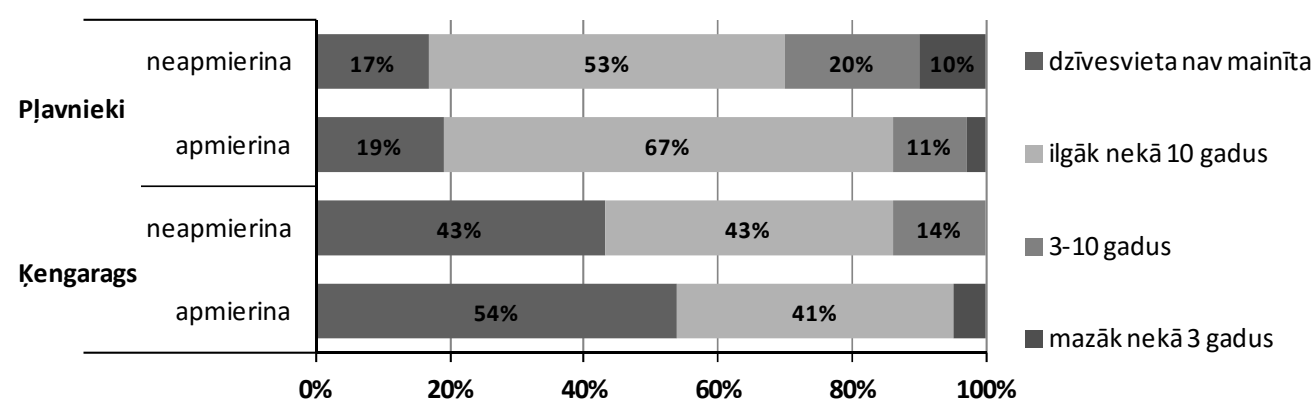

1. attēls. Respondentu dzīves vides pievilcības novērtējums pētījumam izvēlētajās apkaimēs pēc atbilstoši pašreizējā dzīvesvietā nodzīvotajam laikam 
Atsauces

Boren, M., Gentile, M. (2007). Metropolitan processes in post-communist states: an introduction. Geografiska Annaler. Series B: Human Geography, 89B (2), 95-110.

French, R.A., Hamilton, F.I. (eds.) (1979). The socialist city: Spatial structure and urban policy. New York: John Wiley \& Sons.

French, R. A. (1987). Changing spatial patterns in Soviet cities-planning or pragmatism? Urban Geography, 8 (4), 309-320.

Glock, B., Häußermann, H. (2004). New trends in urban development and public policy in eastern Germany: dealing with the vacant housing problem at the local level. International Journal of Urban and Regional Research, 28, 919-929.

Herfert, G., Neugebauer, C. S., Smigiel, C. (2013). Living in residential satisfaction? Insights from large-scale housing estates in central and eastern europe. Tijdschrift voor economische en sociale geografie, 104 (1), 57-74.

Kährik, A., Tammaru, T. (2010). Soviet prefabricated panel housing estates: Areas of continued social mix or decline? The case of Tallinn. Housing Studies, 25, 201-219.

Kempen van, R., Dekker, K., Hall, S., Tosics, I. (2005). Restructuring Large Housing Estates in Europe. Restructuring and Resistance inside the Welfare Industry. Bristol: Policy Press.

Lehmann, S., Ruble, B. (1997). From 'Soviet' to 'European' Yaroslavl: changing neighbourhood structure in post-Soviet Russian cities. Urban Studies, 34 (7), 1085-1107.

Paura L., Arhipova I. (2002). Neparametriskas metodes, SPSS datorprogrammā. Mācību lìdzeklis. Jelgava: LKC.

Pichler-Milanovich, N. (2001). Urban housing markets in Central and Eastern Europe: convergence, divergence or policy 'collapse'. European Journal of Housing Policy, 1, 145-187.

Rīgas dome (2015). Rīgas iedzīvotāju apmierinātība ar pašvaldības darbību un pilsētā notiekošajiem procesiem. Rīgas iedzīvotāju aptaujas rezultātu ziņojums. Pilsētas attīstības departaments.

Rubīns, J. (ed.) (2004). Rīgas dzīvojamais fonds 20. gadsimtāa: Tipologisiskā rakursā. Rīga: Jumava.

Smith, D.M. (1996). The socialist city. In: Andrusz, G., Harloe, M., Szelényi, I. (eds.) Cities After Socialism: Urban and Regional Change and Conflict in Post-Socialist Societies. Oxford: Blackwell, 70-99.

Szelényi, I. (1996). Cities under socialism and after. In: Andrusz, G., Harloe, M., Szelényi, I. (eds.) Cities after Socialism: Urban and Regional Change and Conflict in Postsocialist Societies. Oxford: Blackwell Publishers, 286-317.

Temelová, J., Novák, J., Ouředniček, M., Puldová, P. (2011). Housing Estates in the Czech Republic after Socialism Various Trajectories and Inner Diff erentiation. Urban Studies, 48 (9), 1811-1834.

Treija, S. (2009). Housing and social cohesion in Latvia. In: Holt-Jensen, A., Pollock, E. (eds.) Urban Sustainability and Governance: New Challenges in Nordic-Baltic Housing Policies. New York: Nova Science Publishers, 197-207.

Wassenberg, F. (2004). Large Social Housing Estates: From Stigma to Demolition? Journal of Housing and the built Environment, 19, 223-232.

Wießner, R. (1999). Urban development in East Germany: specific features of urban transformation processes. GeoJournal, 49, 43-51. 


\section{Summary}

Residential areas of the cities in the former Soviet Union and Central Eastern Europe have experienced substantial physical and social transformation since the 1990s. Previous studies have confirmed that the development of residential areas after the demise of socialism is characterized by inner-city change and suburban development. However, these changes affect only a minor part of the urban population while most people still live in large-scale apartment blocks. Moreover, the existing research shows that housing quality, living arrangements and development trajectories of housing estates differ in various locations within the city and also within a given neighbourhood. In order to understand the patterns and factors of inner differentiation in terms of population composition and residential satisfaction, the paper presents a case study from large-scale housing estates located in two different neighbourhoods of Rìga. This study aims to provide insights into residential satisfaction and related characteristics of the inhabitants of the most distinctive type of housing, in the light of post-socialist urban transformations. The analysis is based on a recent sample survey that was carried out in 2015. The research findings reveal that the residential satisfaction of large-scale housing estates by local residents is surprisingly similar in the both neighbourhoods investigated. 